\section{BUDGET}

PERSPECTIVES

2021

PAPER 4

JULY 2020

\section{CHILD POVERTY IN IRELAND AND THE PANDEMIC RECESSION}

MARK REGAN AND BERTRAND MAÎTRE

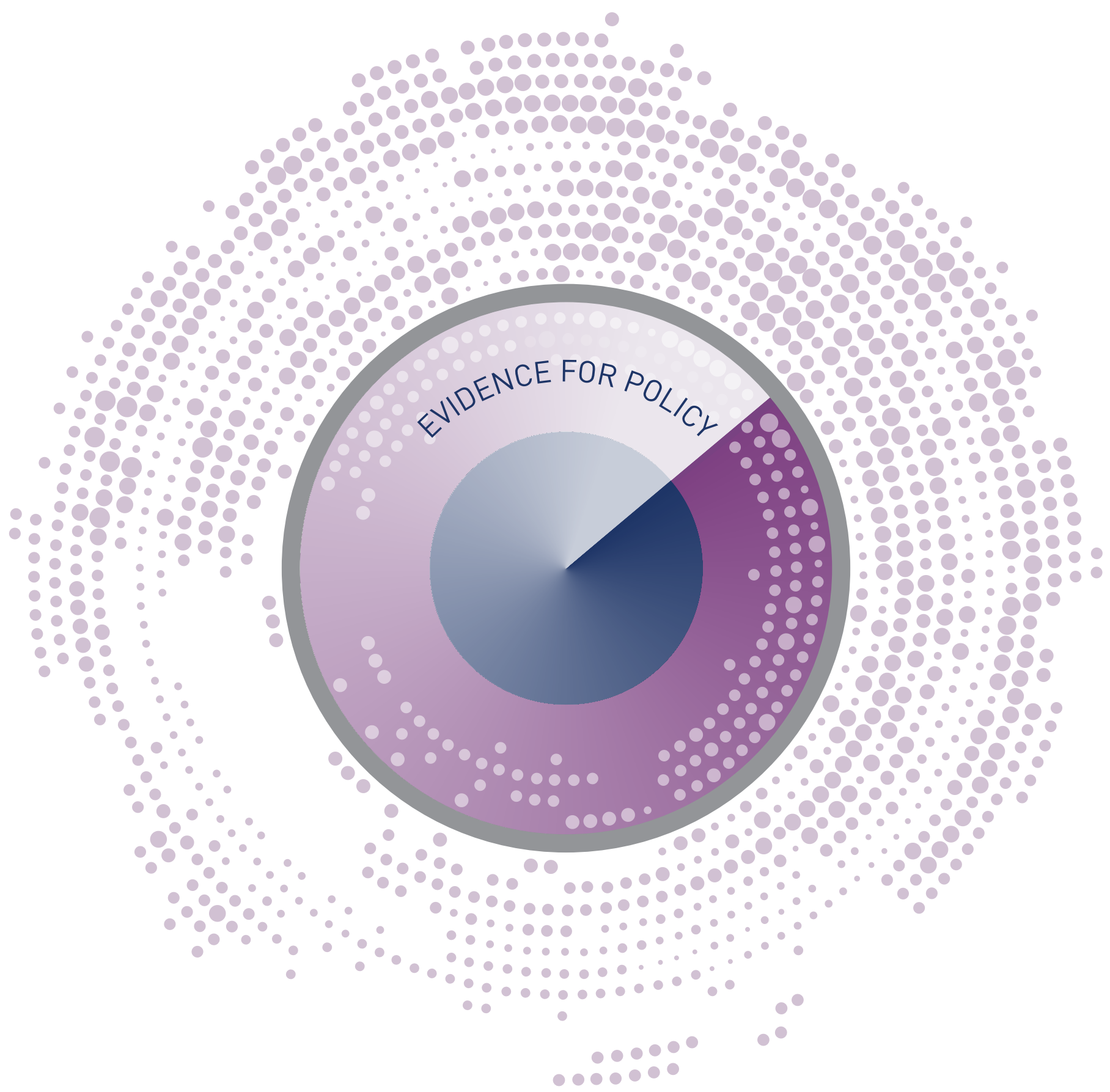




\section{CHILD POVERTY IN IRELAND AND THE PANDEMIC RECESSION}

Mark Regan

Bertrand Maître

July 2020

\section{BUDGET PERSPECTIVES 2021}

\section{PAPER 4}

Available to download from www.esri.ie

DOI: https://doi.org/10.26504/bp202104

(C) 2020 The Economic and Social Research Institute Whitaker Square, Sir John Rogerson's Quay, Dublin 2

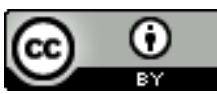

This Open Access work is licensed under a Creative Commons Attribution 4.0 International License (https://creativecommons.org/licenses/by/4.0/), which permits unrestricted use, distribution, and reproduction in any medium, provided the original work is properly credited. 


\section{ABOUT THE ESRI}

The mission of the Economic and Social Research Institute is to advance evidencebased policymaking that supports economic sustainability and social progress in Ireland. ESRI researchers apply the highest standards of academic excellence to challenges facing policymakers, focusing on 12 areas of critical importance to 21st Century Ireland.

The Institute was founded in 1960 by a group of senior civil servants led by Dr T.K. Whitaker, who identified the need for independent and in-depth research analysis to provide a robust evidence base for policymaking in Ireland.

Since then, the Institute has remained committed to independent research and its work is free of any expressed ideology or political position. The Institute publishes all research reaching the appropriate academic standard, irrespective of its findings or who funds the research.

The quality of its research is guaranteed by a rigorous peer review process. ESRI researchers are experts in their fields and are committed to producing work that meets the highest academic standards and practices.

The work of the Institute is disseminated widely in books, journal articles and reports. ESRI publications are available to download, free of charge, from its website. Additionally, ESRI staff communicate research findings at regular conferences and seminars.

The ESRI is a company limited by guarantee, answerable to its members and governed by a Council, comprising 14 members who represent a cross-section of ESRI members from academia, civil services, state agencies, businesses and civil society. The Institute receives an annual grant-in-aid from the Department of Public Expenditure and Reform to support the scientific and public interest elements of the Institute's activities; the grant accounted for an average of 30 per cent of the Institute's income over the lifetime of the last Research Strategy. The remaining funding comes from research programmes supported by government departments and agencies, public bodies and competitive research programmes.

Further information is available at www.esri.ie 


\section{THE AUTHORS}

Bertrand Maître is a Senior Research Officer at the Economic and Social Research Institute and an Adjunct Lecturer at Trinity College Dublin. Mark Regan is a Research Analyst at the Economic and Social Research Institute and a doctoral candidate at University College Dublin.

\section{ACKNOWLEDGEMENTS}

This analysis uses EUROMOD version 12.0+. EUROMOD is maintained, developed and managed by the Institute for Social and Economic Research (ISER) at the University of Essex, in collaboration with national teams from the EU member states. We are indebted to the many people who have contributed to the development of EUROMOD. The process of extending and updating EUROMOD is financially supported by the European Union Programme for Employment and Social Innovation 'Easi' (2014-2020). The results and their interpretation are the authors' responsibility. Funding for the Tax, Welfare and Pensions Research Programme (supported by the Departments of Employment Affairs and Social Protection; Public Expenditure and Reform; Health, Children and Youth Affairs; and Finance) is gratefully acknowledged. We also thank the Central Statistics Office for access to the Survey on Income and Living Conditions Research Microdata files, which were also used in the analysis.

This paper has been accepted for publication by the Institute, which does not itself take institutional policy positions. The paper has been peer-reviewed prior to publication. The authors are solely responsible for the content and the views expressed. 


\section{TABLE OF CONTENTS}

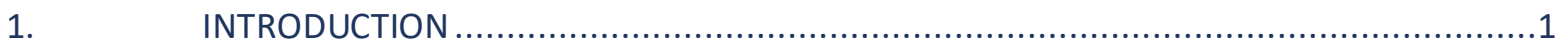

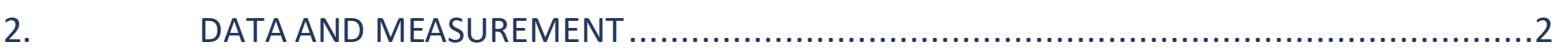

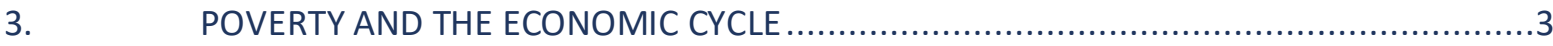

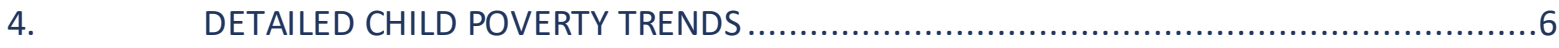

4.1 AGE

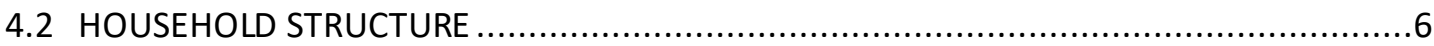

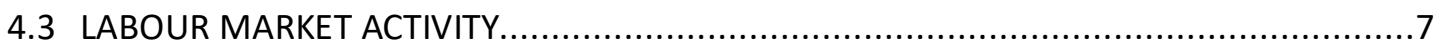

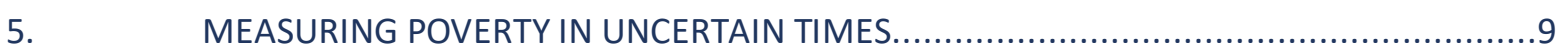

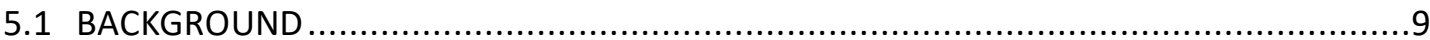

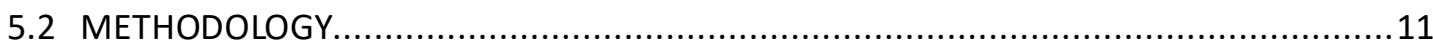

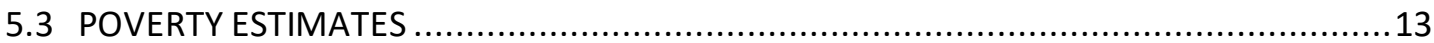

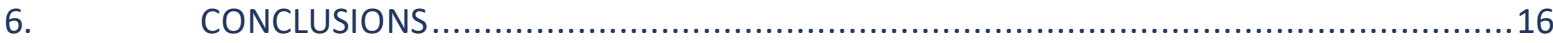

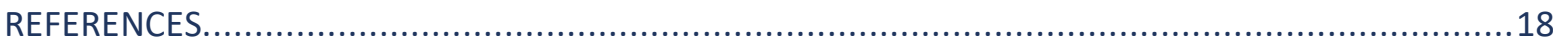

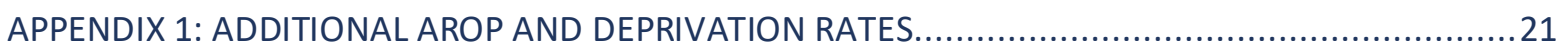

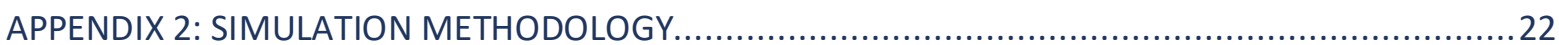





\section{LIST OF TABLES}

TABLE 1 AT RISK OF POVERTY AND DEPRIVATION BY SOCIO-ECONOMIC

CHARACTERISTICS OF CHILDREN, 2008, 2013 AND 2018.

TABLE 2 CHILD INCOME POVERTY TRANSITION MATRIX.................................... 15

TABLE 3 AVERAGE PERCENTAGE CHANGE IN DISPOSABLE HOUSEHOLD INCOME.......16

TABLE A1 PERCENTAGE OF CHILDREN AT RISK OF POVERTY AND DEPRIVED BY HOUSEHOLD TYPE AND MAIN ACTIVITY OF THE HEAD OF HOUSEHOLD, 2007-2018 ........21

TABLE A2 RANGE OF SIMULATED EMPLOYMENT LOSSES BY INDUSTRY .....................24

TABLE A3 PORTION OF DISPLACED WORKERS WHO RECEIVE PUP AND TWSS .............24

TABLE A4 RANGE OF THE RECOVERY PARAMETERS........................................... 24

\section{LIST OF FIGURES}

FIGURE 1 AT-RISK OF POVERTY AND BASIC DEPRIVATION RATES BY AGE GROUP, 20042018 



\section{ABBREVIATIONS}

$\begin{array}{ll}\text { AROP } & \text { At risk of poverty } \\ \text { CSO } & \text { Central Statistics Office } \\ \text { DEASP } & \text { Department of Employment Affairs and Social Protection } \\ \text { PUP } & \text { Pandemic Unemployment Payment } \\ \text { SILC } & \text { Survey on Income and Living Conditions } \\ \text { TWSS } & \text { Temporary Wage Subsidy Scheme }\end{array}$




\title{
Child Poverty in Ireland and the Pandemic Recession
}

\begin{abstract}
The Irish experience of the Great Recession was characterised by a large increase in unemployment, little change in relative poverty measures but a large increase in basic deprivation, which affected children worst. We show that, from 2004 to 2018, parental employment and high household work intensity decreased the risk of a child living in poverty. In the face of widespread COVID-19 employment losses, we simulate how child income poverty rates will evolve over the course of 2020. Without an economic recovery, child income poverty rates could rise as high as 23 per cent, a one-third increase in the rate relative to the start of 2020. A partial economic recovery decreases the surge in child income poverty, which rises to a maximum of 19 per cent, a one-seventh increase in the rate relative to the start of 2020. We conclude that a partial economic recovery in the latter half of the year, coupled with an extension of emergency income supports for the entirety of 2020, would bring child income poverty levels only moderately above the level they would have been at in a counterfactual where COVID-19-related job losses did not occur (an average increase of between one-eleventh to a maximum of oneseventh).
\end{abstract}

\section{INTRODUCTION}

Over the course of the Great Recession in Ireland, children suffered the worst outcomes on all poverty measures. Indeed, as the national unemployment rate increased from 5 per cent in 2007 to 15 per cent in 2012 at the peak of the recession, children's material deprivation - an inability to afford basic items increased from 16 to 32 per cent. Despite poverty rates for all ages decreasing in the interim, by 2018 child poverty rates were still higher than those observed for working-age adults or older people.

In the latest year for which we have data available, 2018, the income poverty rate for children was 16 per cent, while it was 14 per cent for working-age adults and 11 per cent for people aged 65 and over. Child poverty is a concern for policymakers as poverty has negative short-run effects on children and can also induce long-run negative effects that persist into adulthood (see Duncan et al., 2012). There has been extensive research on the negative consequences of child poverty across a wide range of domains, from academic outcomes to health, social participation and socio-emotional outcomes (Duncan \& Brooks-Gunn, 1997; Department for Work and Pensions, 2007; Bolger et al., 1995). A commonality of this literature is that parental employment is frequently cited as a significant factor in preventing child poverty and in transitioning out of poverty (ILO, 2005; Caputo, 1991; OECD 1998, 2004). 
The world economy now faces into a severe COVID-19-induced recession. On the domestic front, the Irish economy has been predicted to contract by 12 per cent (baseline scenario) over the course of 2020 (McQuinn et al., 2020). The labour market faces a large swing, with unemployment rates rising from historically low levels of less than 5 per cent in February 2020 to a high of 24 per cent in the second quarter of 2020 (McQuinn et al., 2020). To monitor developments in the Irish labour market, the Central Statistics Office (CSO) began to publish a COVID-19adjusted unemployment rate. The series reported an unemployment rate of $28 \mathrm{per}$ cent in April 2020. ${ }^{1}$ Beirne et al. (2020) show that employment losses from COVID19 heavily reduced household incomes; one can assume that this will have knockon effects on living standards and the risk of exposure to financial difficulties with arrears and debts.

With the possibility of such dramatic consequences, we explore the probable impact of the pandemic on income poverty rates, particularly for children, over the course of 2020. We preface this analysis by analysing how poverty evolved in Ireland over the course of the Great Recession. In Section 3, we document the poverty trends observed during the Celtic Tiger period, Great Recession and subsequent recovery. In Section 4, we present the socio-economic profile of children that were the most exposed to poverty during these periods, and highlight the poverty-reducing role of parental employment. In Section 5 , we conclude by presenting the results of an empirical exercise where we estimate how COVID-19related employment losses and emergency income support measures affect poverty under various assumptions on the trajectory of economic recovery in the latter half of the year.

\section{DATA AND MEASUREMENT}

The data analysis in Sections 3, 4 and 5 are based on the CSO Survey on Income and Living Conditions (SILC), ${ }^{2}$ an annual household survey conducted by the CSO since 2003. The purpose of SILC is to collect household and individual information across a wide range of topics such as household and individual income, living conditions, housing conditions, labour market status, education, health, etc. SILC is the national data source to monitor poverty and to produce poverty indicators such as 'at risk of poverty', basic deprivation and consistent poverty, which combines the former two poverty measures. In 2017, the SILC sample comprised 5,029 households, giving a total of 12,612 individuals. In the first empirical part of this paper, we analyse children's experience of poverty by using two key national poverty measures: the 'at risk of poverty' (AROP) indicator and the measure of basic deprivation. The AROP indicator is a relative measure that identifies the

1 The CSO COVID-19-adjusted unemployment rate differs from the ILO definition as it includes workers who are not working due to unemployment as well as those not working and in receipt of the COVID-19-related financial measure.

2 The research microdata file (RMF) is used in Sections 3 and 4, while the EU-SILC User Database (UDB) is used in Section 5. 
proportion of the population with a household disposable equivalised income ${ }^{3}$ below 60 per cent of the national median. The measure of basic deprivation, an absolute measure, is a non-monetary indicator that identifies the enforced absence of basic goods and services that are regarded as essentials. A household is deprived when the household cannot afford to have at least two basic items out of a list of eleven items, including adequate food, clothing, heating for the home and participation in social activities (Maître B., Nolan B. and Whelan C., 2006).

\section{POVERTY AND THE ECONOMIC CYCLE}

In Figure 1 we report two measures of poverty: the AROP rate and the basic deprivation rate across three age groups, as well as the unemployment rates over the period as a proxy for the economic recession. Figure 1 shows that, over time, children have experienced consistently higher AROP and deprivation rates than working-age adults and older people. Looking at the AROP rate first, in the earliest SILC years, adults tended to have the lowest AROP rates. In 2004, the working-age population (18-64) had a rate of 17 per cent; it was highest, at 27 per cent, for those aged 65 or older. The AROP rate for children was 23 per cent. Through the economic boom and the initial period of economic decline, from 2004 to 2010, all age groups experienced a decrease in AROP rates. This decrease was particularly sharp for those aged 65 and over. By 2010, AROP rates for older people were below 10 per cent, below 15 per cent for the working-age population and just below 20 per cent for children. Up to 2009, the increase in the rates of social welfare payments had been particularly effective in reducing poverty among older people. During the earlier period of the recession, basic pension rates were preserved, which protected older people from the worst effects of the recession (Watson and Maître, 2013).

Despite the onset of the Great Recession, when unemployment rates reached a high of 15 per cent, AROP rates for all ages remained relatively stable (see Figure 1). They increased only slightly for older people (to approximately 10 per cent) and working-age adults (to just over 15 per cent) while staying constant at around 20 per cent for children. The second chart in Figure 1 reports the income poverty rates anchored in time; that is, using the 2004 income poverty line adjusted for inflation over time. Unlike the previous chart, it shows that all age groups experienced a fall in their AROP rates until 2009, before the rates rose during the recession up to 2012/2013 and fell again during the period of economic recovery. The AROP anchored in time still shows the same pattern of disadvantage between groups: children experience the highest income poverty rate. 
The small variations in the AROP indicator during the Great Recession shown in the first chart highlight the limits of a relative measure to capture economic fluctuations as experienced in Ireland (Watson et al., 2017). It points to the need to supplement relative income measures with direct measures of living standards, such as the basic deprivation indicator. ${ }^{4}$

The measure of material deprivation, based on an absolute threshold, shows a similar pattern of disadvantage between age groups, but deprivation rises systematically with the onset of the Great Recession. Up to 2007, deprivation rates were lower than AROP rates for all age groups. From 2007 onward, the rate of deprivation increased sharply, whereas AROP rates varied little. From 2007 to 2013, deprivation rates rose from 8 to 15 per cent for older people, from 10 to 30 per cent for working-age adults and from 15 to 37 per cent for children. From 2013, the rate of deprivation fell for all age groups, but children remained the most disadvantaged of all groups.

$4 \quad$ Poverty lines are calculated independently for each year; AROP rates for children, adults and older people are simply the portion of each group living below this line. Large changes in incomes during an economic expansion/contraction are often captured in movements of the poverty line itself (up/down) as opposed to changes in the portion below the line. Large income changes, thus, are often captured in poverty line movements as opposed to AROP rates. 

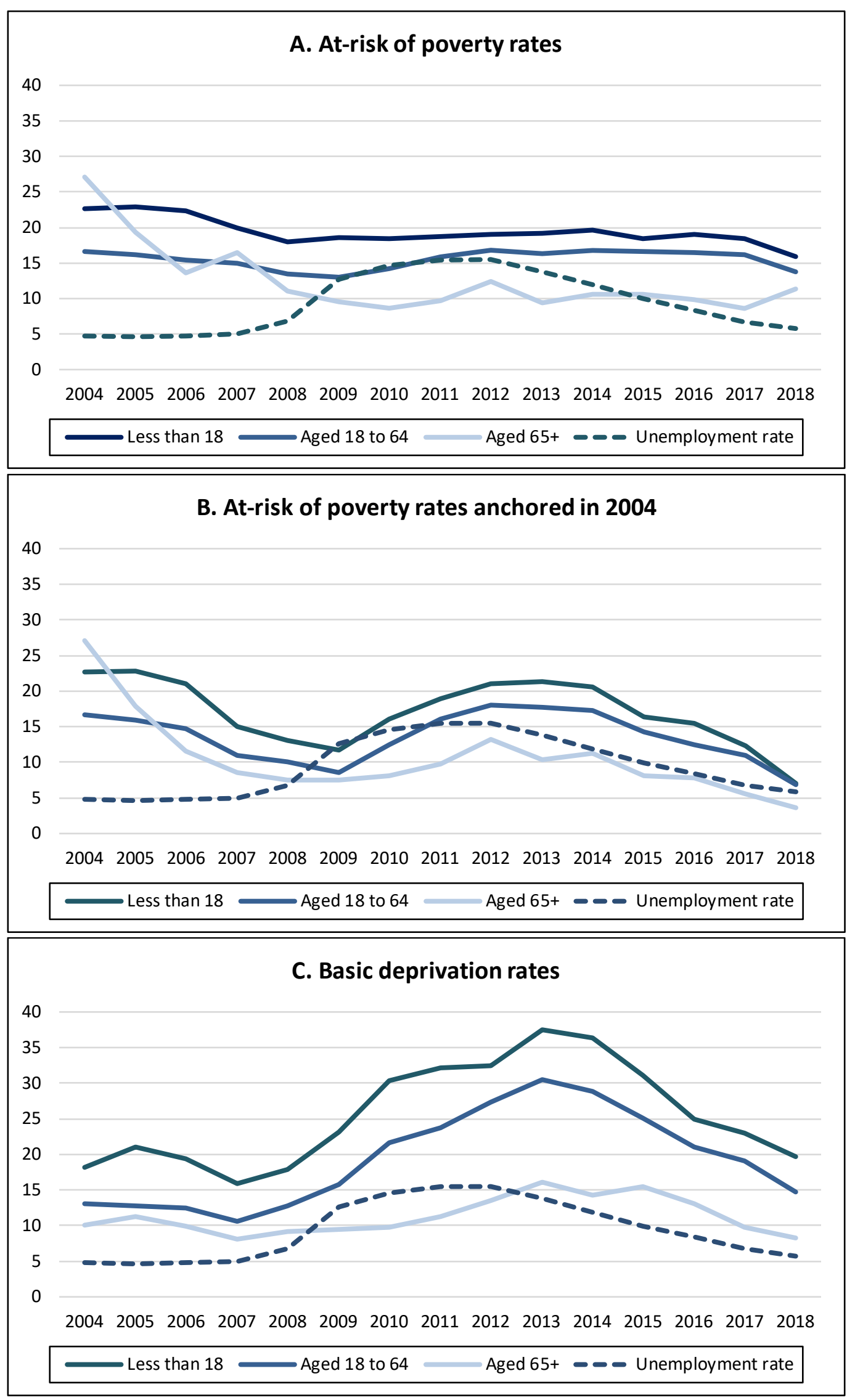

Source: Authors' analysis using CSO SILC RMFs and CSO Labour Force Survey StatBank. 


\section{DETAILED CHILD POVERTY TRENDS}

While aggregate child poverty rates have not varied with patterns in the economic cycle, there have been significant differences in the experiences of child poverty across family types. In Table 1, we show how AROP rates and material deprivation vary across different sub-groups of children, based on key socio-economic traits. To give a sense of how cyclical these AROP and deprivation rates might be, we compare three distinct points in time. We compare these rates from 2008, at the outset of the Great Recession; from 2013, one of the peaks of the recession, and from 2018, when the economy had fully recovered.

\subsection{Age}

We categorise children into three age groups, corresponding broadly to preprimary school (0 to 5), primary school (6 to 11 ) and secondary school age (12 to 17). The AROP rates tend to increase in a linear fashion with age in all years. ${ }^{5} A R O P$ rates are as low as 13 per cent for the youngest age group but rise to a high of 22 per cent for the oldest group in 2008. AROP rates for children in these age categories rise only slightly between 2008 and 2013. The age pattern of basic deprivation varies substantially from 2008 to 2013. First, in 2008 the risk profile with age is reversed, with the youngest children reporting the highest level of deprivation, at 21 per cent. Second, in 2013, all age groups experienced a much larger increase in deprivation than observed in AROP rates; basic deprivation doubled for the two older age groups, and they now show the highest level of deprivation. By 2018, the Irish economy had fully recovered and all age groups had experienced a fall in their AROP and a sharp reduction in their level of deprivation. The youngest age group enjoyed the largest reduction in AROP, at 9 per cent, while all age groups had their deprivation rates almost halved compared to 2013.

\subsection{Household Structure}

In 2008, the majority of children lived in two-adult households with up to three children (58 per cent). A smaller portion lived in large households comprised of two or more adults with children ( 27 per cent $)^{6}$ and the remainder ( 15 per cent) in oneadult households. ${ }^{7}$ Children in one-adult households had the highest AROP rate in 2008, at 40 per cent. Children in two-adult households had the lowest, at 11 per cent, while children living in other households had AROP rates of 20 per cent. From 2008 to 2018 there was little change in AROP rates for one-adult and two-adult households. The AROP rate for other household types did increase, however, rising from 20 per cent in 2008 to 28 per cent by 2013. There was a similar decrease from 2013 to 2018, and by 2018 AROP rates were as low as 18 per cent. The risk pattern

5 While the change of equivalence scale giving an adult value from the age of $14+$ contributes to increase the AROP of older children, other household characteristics are likely to contribute too, but such exploratory work is beyond the scope of the paper.

6 Labelled 'other households' in Table 1. We refer to these as 'other households' in the remainder of the text.

7 Authors' calculations not shown in Table 1. 
across household types for basic deprivation is similar to the AROP rate in 2008 . Highest deprivation rates are observed in one-adult households (39 per cent) and the lowest in two-adult households (13 per cent). Deprivation rates rose by close to 20 percentage points for one- and two-adult households by 2013 and just under 17 points for other households. By 2013, the deprivation rate for children in oneadult households was extremely high, at 64 per cent - twice that of children in twoadult households. By 2018 the level of deprivation for all household types had fallen to almost pre-recession levels, but the reduction was lowest for children in one-adult households. Previous research has shown that Irish lone parents are more likely to experience poverty (Watson et al., 2016; Grotti et al, 2017). This ties in with work by Doorley et al. (2018) and Regan and Keane (2018) which highlights that, over the austerity period, discretionary policy changes particularly affected the incomes of lone parents.

\subsection{Labour Market Activity}

An extensive body of research shows that the work status of adults (particularly of the mother) and the presence of other workers in the household are the main protective factors against child poverty (European Commission, 2016; Watson, Maître and Whelan, 2012). In 2008, 11 per cent of children were AROP when the head of household was at work. AROP rates were much higher, at 34 (41) per cent for children where the household head was unemployed (inactive). In 2013, the poverty protection offered by parental employment became even more evident. The risk of income poverty fell to 8 per cent for children where the household head was at work, and stayed the same in 2018. AROP rates rose noticeably to a high of 47 per cent for children in households where the household head was unemployed and reached 49 per cent in 2018. Employment of the household head also offers a similar protection effect against basic deprivation.

While the employment status of the household head has important implications for the risk of child poverty and deprivation, the labour-force status of all adults in the household is also important. We use a methodology developed by Eurostat to calculate the amount of available work-time spent at work by potential earners in a household (European Commission, 2010). ${ }^{8}$ Children in jobless or low work intensity households had very high AROP rates from 2008 to 2018, ranging from 57 to 63 per cent. Deprivation rates for these households rose from 52 per cent in 2008 to nearly 75 per cent in 2013, before falling in 2018 but to levels higher than observed in 2008. AROP and deprivation rates tend to linearly decrease by overall household work intensity in all periods. Children in households classified as having high \very high work intensity had low AROP rates. These are close to 5 per cent 
from 2008 to 2018. Children in these work-intensive households also had the lowest deprivation rates.

We also examine the intersection of household structure and labour market activity. From 2008 to 2018, deprivation rates fell substantially for children in oneadult, two-adult and other household types where the head of the household was in work as opposed to unemployed or inactive in the labour market. However, even when the head of household was in work, there are still large disparities in the experience of poverty between household types, with higher risk in one-adult households. This highlights that household structure is also a determinant for children having a higher standard of living, along with parental employment. In Appendix 1, we show AROP and deprivation rates by household type and the labour market activity of the head of household.

TABLE 1

AT RISK OF POVERTY AND DEPRIVATION BY SOCIO-ECONOMIC CHARACTERISTICS OF CHILDREN, 2008, 2013 AND 2018

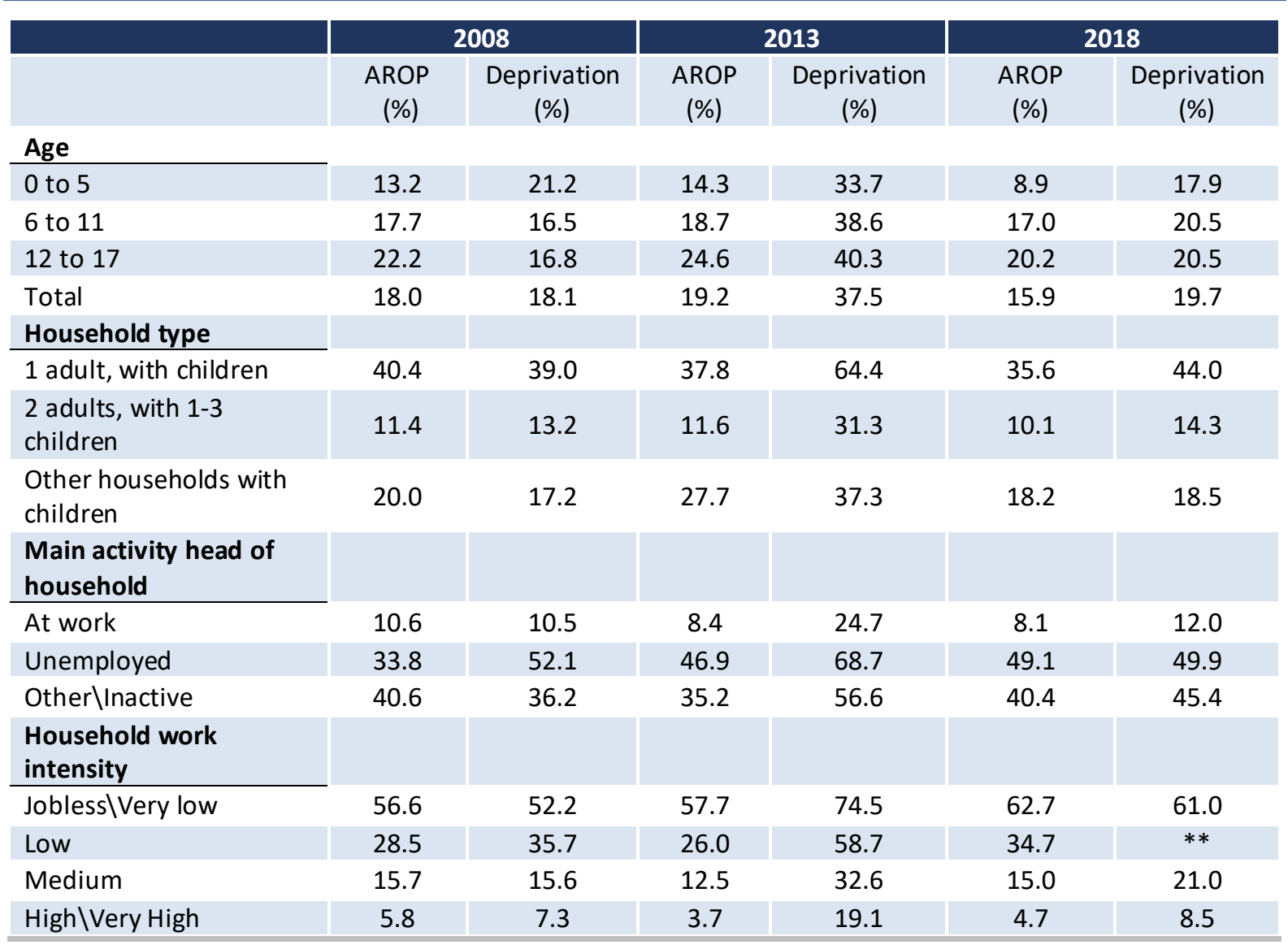

Source: Authors' analysis using the 2008, 2013 and 2018 SILC RMFs

Notes: 'AROP' is the 'at risk of poverty' measure. 'Deprivation' is the rate of basic deprivation. A child is defined as an individual less than 18 years of age. The household work intensity measure is derived using a European Commission methodology; see Section 4.3 for further details. The double asterisk $\left(^{* *}\right)$ indicates a blank cell due to insufficient sample cases as per the CSO statistical disclosure guidelines. 


\section{MEASURING POVERTY IN UNCERTAIN TIMES}

\subsection{Background}

In the previous section, we highlighted the poverty-reducing effect of employment of household members. Children in households with an employed head or where there is a high degree of labour market activity in the household are less likely to be at risk of poverty or to be deprived. In this section, we estimate how child income poverty in Ireland in 2020 will be affected by the unprecedented employment losses stemming from COVID-19. We examine how income changes from employment losses and emergency income-support measures will affect income poverty rates for the coming year. While deprivation rates also provide important information on living standards, estimating how (self-reported) deprivation would evolve through 2020 would require real-time survey data from households. Since objective changes in income and income poverty levels can be more readily estimated by statistical techniques than can self-reported deprivation levels, we opt to focus solely on income poverty in the following analysis.

As COVID-19 became active in the country, the Irish Government introduced emergency legislation to dampen the spread of the virus. This culminated in the closure of schools, colleges and public buildings from 13 March 2020. All nonessential retail outlets closed by 28 March, while essential retail outlets had to regulate capacity in order to maintain social distancing between consumers. These extreme administrative closures were continued until 18 May. After this point a phased plan to reopen businesses came into effect. The phased opening of the economy would take place over the course of summer 2020 as long as COVID-19 caseloads were at acceptable levels.

This administrative closedown had wide economic repercussions. Close to a quarter of enterprises ceased trading either temporarily or permanently, while three-quarters of enterprises experienced lower than normal revenues over the period 4 to 17 May (CSO, 2020a). Inevitably, business closures resulted in widespread job losses. In response to this sudden and unforeseen economic crisis, the Government introduced two large-scale emergency income-support measures to smooth the incomes of affected workers.

The first of these, the COVID-19 Pandemic Unemployment Payment (PUP), was introduced on 12 March, at a rate of $€ 203$ per week, which was raised to $€ 350$ by the end of the month. By 21 March, 58,600 individuals had availed of the scheme; by the week ending 21 April, 584,000 payments had been issued - a tenfold increase in the space of a month (DEASP, 2020). Between 29 June and 10 August, the scheme was to move towards a two-tier system. Claimants whose prior earnings were less than $€ 199.99$ received a payment of $€ 203$ per week while those earning $€ 200$ or more received a rate of $€ 350$ each week.

The Temporary Wage Subsidy Scheme (TWSS) was introduced on 24 March as another emergency income-support response. The TWSS was aimed at maintaining 
links between employers and employees in businesses strongly affected by the pandemic. ${ }^{9}$ Employers availing of the scheme maintain the employee on their payroll system and the Government pays the firm a subsidy based on the average net weekly wage of the employee. Employers are also eligible to pay PRSI at a heavily reduced rate $(0.5$ per cent) which helps compensate for additional nonwage labour costs. By 23 April, 35,200 employers had received subsidy payments and 337,400 employees had received at least one payment under the scheme (Revenue Commissioners, 2020a). As of 4 May, the TWSS offered subsidies in a tiered system based on an employee's previous average net weekly wage after accounting for income tax, universal social charge and employee PRSI. The subsidy payments based on previous net earnings are outlined below.

- Employees earnings less than €412 net per week: employers receive a subsidy of 85 per cent of the net wage.

- Employees earnings $€ 412$ to $€ 500$ net per week: employers are paid a flat subsidy of $€ 350$.

- Employees earning $€ 500$ to $€ 586$ net per week: employers are paid 70 per cent of their net wage, with a cap of $€ 410$ applying.

- Employers are free to pay employees the remainder of their net wage in a gross 'top-up' payment so long as they earn less than €586 per week.

- For employees earning €586 or more per week, the level of state subsidy provided is related to the gross top-up payment paid by the employer:

- Employers who pay top-ups that restore an employee's net earnings to 60 per cent or less of their previous net wage receive a subsidy of $€ 350$ per week.

- Employers who pay top-ups that restore employee net earnings above 60 per cent but not more than 80 per cent of net earnings receive a subsidy of $€ 205$ per week.

- No subsidy is payable where the employer top-up brings net wages above 80 per cent of previous net earnings.

Some additional income-support measures were introduced. The Fuel Allowance season was extended by one month. A special COVID-19 Illness Benefit payment was also introduced. It is available at a higher rate of payment than traditional Illness Benefit and with no six-day phase-in period. It is available for workers forced to self-isolate due to COVID-19 and unable to work as a result.

Of course, employment losses would reduce labour market earnings of households. However, the emergency income supports would replace a portion of, or even increase, incomes of households with displaced workers. In the face of

9 These wage retention schemes have been adopted internationally, with the United Kingdom implementing the Coronavirus Job Retention Scheme and Australia introducing the JobKeeper Payment. 
these large employment losses but a rising public social safety net, it is unclear, a priori, how income poverty rates, as calculated over disposable income, will change. To assess this, we model both widespread employment losses and the ensuing emergency income-support measures ${ }^{10}$ to highlight the net impact on income poverty.

\subsection{Methodology}

We simulate employment losses and emergency income-support measures by using a microsimulation approach. We use the 2017 Irish file of the EU-SILC Survey on Income and Living Conditions along with the tax-benefit model EUROMOD to estimate income poverty and income changes stemming from the pandemic. EUROMOD is a European-wide tax-benefit microsimulation model. It processes the detailed reported labour market and demographic information of individuals in EUSILC and calculates their, and other household members', tax liabilities and social welfare entitlements based on the tax-benefit rules in place in Ireland during 2020. Employee and self-employed incomes are uprated to the start of 2020 levels to better represent the initial earnings distribution.

We simulate employment losses by modifying the SILC data to make random samples of workers unemployed. These employment losses are implemented to match the uptake of PUP and TWSS by industry. We simulate employment losses to match the number of recipients of PUP and TWSS at a snapshot in time, namely the end of April 2020. On 21 April, 584,000 claims of PUP were paid and by 23 April 337,000 employees had received at least one payment under the TWSS. The number of recipients receiving the TWSS is cumulative and will overstate the number in receipt of the scheme at the end of April. To gain a more accurate snapshot of employment losses, we approximate that 250,000 claims under the TWSS were paid on 23 April. Recent administrative data show that 235,300 claims under TWSS were paid on 17 April while 284,800 were paid on 23 April (Revenue Commissioners, 2020b). This indicates that our approximation of a quarter of a million recipients of the TWSS provides an accurate snapshot of the scale of the scheme. Thus, we simulate an overall baseline of 834,000 job losses, with 584,000 of these then receiving PUP and the remaining 250,000 qualifying for TWSS.

We model the following emergency income-support measures.

- PUP of $€ 350$ for all workers from Mid-March to the end of June. We do not model the initial $€ 203$ rate as this was only briefly in place. The scheme then transitions to a two-tier system, with those previously earning less than $€ 199.99$ receiving $€ 203$ per week and those previously earning $€ 200$ or more per week receiving €350 per week. We assume that this tiered

10 We do not model the effect of the new COVID-19 Illness Benefit payment as this would require assumptions about the spread of the virus among workers. This is beyond our expertise and would require large, speculative assumptions. The payment is only available for a maximum of 14 days so it is also less likely to be as financially impactful as the PUP or TWSS. 
system is in place for the remainder of the year.

- The Temporary Wage Subsidy Scheme as described in Section 5.1. We assume that this scheme is in place for the remainder of the year.

- The one-month extension of the Fuel Allowance payment.

We also warn of the likely scale of income poverty changes in the event of an economic recovery. We analyse two separate scenarios: Scenarios A and B, where initial employment losses and emergency response measures are identical, but the degree of labour market recovery in the latter half of the year varies. In Scenario A, there is no economic recovery and no displaced workers return to work. The lack of an economic recovery may be thought unlikely, but it is a useful scenario to analyse as it provides a floor to income losses we can expect households to incur if the present downturn persists through the year. In Scenario B, a random portion of displaced workers return to work in the middle of June and a further portion return to work at the end of September. We allow for between 61 and 82 per cent of displaced workers to return to work by the end of September. ${ }^{11}$ These job-finding rates are adapted from quarterly unemployment projections reported by the Central Bank (2020).

We incorporate earnings dynamics in the labour market recovery process. The Department of Finance (2020) has predicted that earnings per employee will decrease by 7.6 per cent in 2020 . We incorporate this prediction by reducing the earnings of displaced workers returning to work by a random 10 to 15 per cent, while freezing earnings of workers who do not lose employment. This accounts for earnings losses among workers but also adjusts the earnings of displaced workers in line with the substantial literature on wage scarring, which shows that spells out of the labour market affect future earnings (Savage et al., 2014; McGuinness et al., 2009).

We offer one novel contribution to empirical Irish policy analysis. We repeatedly simulate job losses (in Scenarios A and B) and the return to work of displaced workers (Scenario B only) over different random samples of workers, using a Monte Carlo framework (see Appendix 2 for more details on the simulations and scenarios analysed). This allows us to calculate the change in income poverty rates brought about through employment losses, and subsequent return to work, over the entire earnings distribution in an industry. This enables us to estimate numerous income poverty outcomes and, most importantly, to quantify the likely range of income poverty changes - a feature of great importance in such economically uncertain times. In total, we estimate a range of income poverty rates from Scenario A and B

11 This is a simplification of the labour market rebound process into two points in time. We would expect displaced workers to return to work in more granular intervals rather than at two discrete points in time. However, adding such complexity to the job-creation process brings a large degree of computational complexity and would require very detailed monthly unemployment rate projections. 
over 100 iterations using EUROMOD and the Irish EU-SILC data.

In Section 3 we showed that child income poverty rates, using relative poverty measures, did not vary during the Great Recession, but that absolute measures of poverty - either deprivation or income poverty using an anchored poverty line - rose substantially. In the following analysis, we use an anchored measure of income poverty, meaning that the income cut-off for being classified as poor is the same in Scenario $A$ and $B$. We estimate the income poverty line from a counterfactual where the COVID-19 pandemic did not occur, and incomes and employment levels remain at Q1 2020 levels. We call this counterfactual the No Pandemic Baseline. This fixed income poverty line approach is in line with Bronka et al. (2020) who analyse the effect of COVID-19 employment losses and emergency policy measures on incomes and poverty in the United Kingdom. ${ }^{12}$ We compare how estimated income poverty rates vary in Scenario $A$ and $B$ and compare these to income poverty levels from the No Pandemic Baseline in order to estimate how income poverty has evolved due to COVID-19 job losses and emergency income-support measures.

\subsection{Poverty Estimates}

In Figure 2 we display our estimated income poverty rates for children, for workingage adults and for the entire population. We distil the results of our 100 simulations, for Scenario A and B respectively, by displaying the minimum, mean and maximum income poverty rate, using an anchored poverty line, for each category over the 100 simulations.

In Scenario A, where no economic recovery occurs, child income poverty rates tend to increase sharply compared to the No Pandemic Baseline. Child income poverty rises from a baseline level of 16.6 per cent to at least 19.5 per cent and at most 22.6 per cent. Allowing for a labour market recovery in Scenario B decreases these high rates of child income poverty dramatically: to a low of 16.8 per cent and a high of 19 per cent. A similar pattern is noticeable in income poverty rates for working-age adults. Income poverty rates rise from 12.9 per cent to an average of 15.1 per cent in Scenario A but rise just slightly, to an average of 13 per cent, in Scenario B. Income poverty rates in the population tend to closely track both the level and movements in working-age adult income poverty as working-age adults comprise a large portion of the population.

These income poverty estimates highlight that a return to work for displaced workers, coupled with the continuation of emergency income-support measures, leave income poverty levels closer to the levels that would have been observed in the absence of a pandemic and large labour market shock. Child income poverty rates rise by an average of 1.4 percentage points (equivalent to an 8 per cent

12 We estimate a fixed poverty line of $€ 11,572$ per a nnum based on simulated income sources in EUROMOD. We also repeat our analysis with the 2018 poverty line from observed incomes in SILC 2018 adjusted for inflation between 2018 and March 2020, which yields a poverty line of $€ 13,940$. Poverty rates are higher with this adjusted 2018 poverty line but the change in poverty rates between the No Pandemic Baseline and Scenarios A and B is similar. 
increase). On the other hand, our estimates show that emergency income-support measures alone have not been strong enough to completely smooth the income losses families face. In the absence of a resurgence in the labour market, income poverty levels for children will increase by an average of 4.5 percentage points (equivalent to a 27 per cent increase).

Given that the evolution of child income poverty rates is contingent on economic recovery, we investigate whether the composition of children living in income poverty has changed in Scenarios A and B relative to the No Pandemic Baseline. While child income poverty rates increase substantially in Scenario A and only moderately in Scenario B, this does not necessarily mean that the same children are living in income poverty in all scenarios. The rising social safety net brought about through emergency income-support measures has left some households who have faced an employment loss financially better off in the short-term (Beirne et al., 2020). Redmond (2020) also notes that the €350 PUP payment is 50 per cent higher than the gross weekly wage of the average minimum-wage employee in the retail and accommodation \& food sectors. Therefore, these income gains could lift some previously poor households out of income poverty, while previously higher-earning households, who would not be left better off availing of the PUP scheme, could fall below the income poverty line.

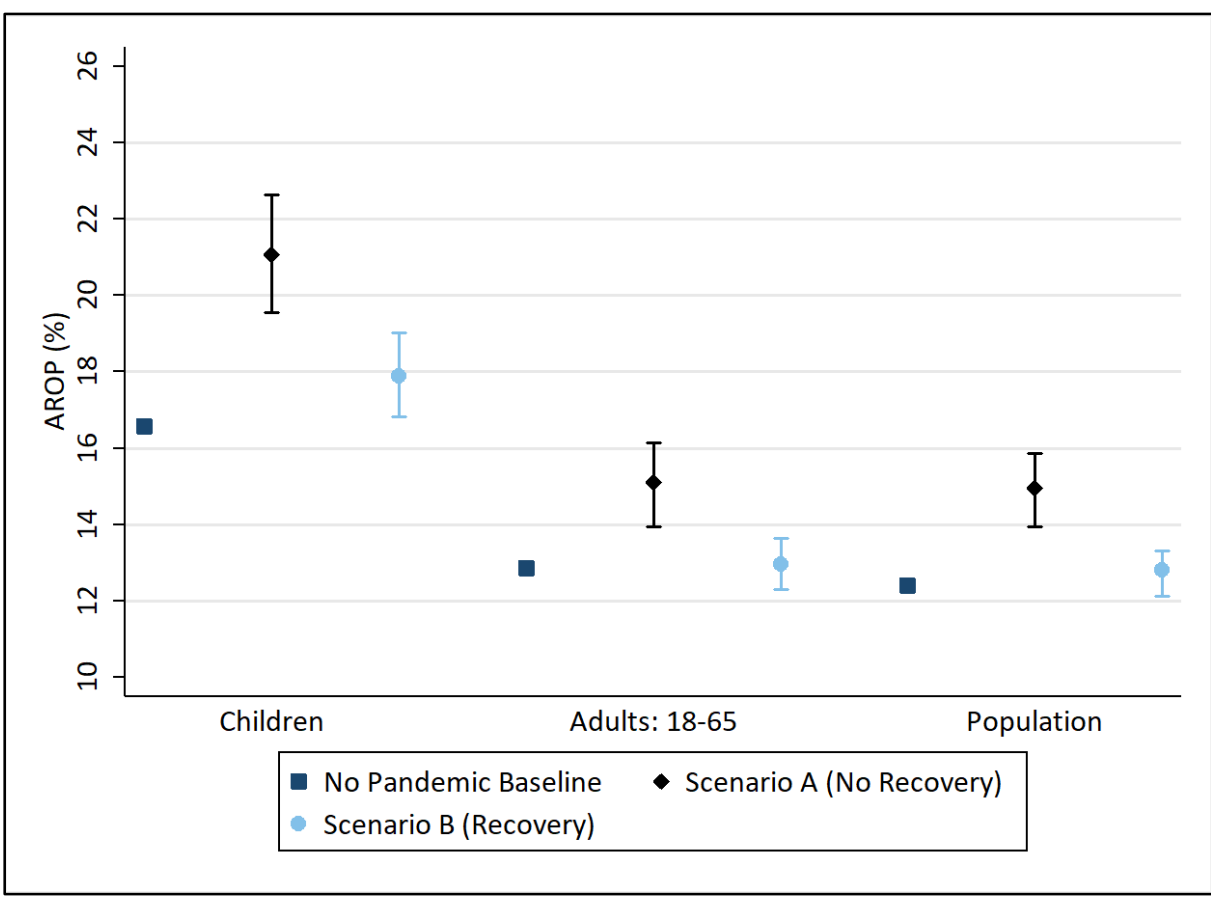

Source: Authors' estimates using EUROMOD and 2017 Irish EU-SILC UDB, with incomes uprated to start of 2020 levels. Note: $\quad$ Shapes are averages calculated over 100 iterations of Scenario A and B. The capped tails represent the minimum and maximum income poverty rate simulated over 100 iterations of Scenario A and B respectively. The income poverty line is calculated as 60 per cent of the median equivalised household disposable income in the No Pandemic Baseline scenario. This income poverty line is used in all three scenarios. This means that income poverty rate changes are only due to income changes and not to movements in the income poverty line. The $y$-axis shows the atrisk of poverty rate; i.e. the portion of each group living below the income poverty line. 
Despite these concerns, we find limited evidence of 'swapping' of children below and above the income poverty line across scenarios. In Table 2 we tabulate children's poverty status in the No Pandemic Baseline against their poverty status in Scenarios $A$ and B. In Scenario A, we see that there are quite large falls into income poverty: an additional 3.2 to 6.3 per cent of children now live below the income poverty line. Despite income gains being possible, if a worker earns less than their relevant PUP rate, these gains are not large enough to move many previously poor children above the income poverty line; between 0.1 and 1.1 per cent of children rise out of income poverty in this way. With an economic recovery, Scenario B, a much smaller portion of children fall into income poverty. Just 1.1 to 3.0 per cent fall below the baseline income poverty line. The portion of children rising out of income poverty also remains very low, but is similar to Scenario $A$, at 0.1 to 1.2 per cent of children. Overall, it appears that, in both Scenario A and B, income losses in previously nonpoor households tend to move a significant portion of children (as high as 6.3 per cent in A and 3.0 per cent in B) below the baseline income poverty threshold. Despite income gains being evident for some households after accounting for employment losses and emergency income supports as outlined in Beirne et al. (2020), these income gains are neither large enough, nor pervasive enough, to lift many previously poor children out of income poverty.

\begin{tabular}{|c|c|c|c|c|c|}
\hline & & \multicolumn{2}{|c|}{ Scenario A (No Recovery) } & \multicolumn{2}{|c|}{ Scenario B (Recovery) } \\
\hline & & $\begin{array}{c}\text { Not Poor } \\
\text { (\%) }\end{array}$ & $\begin{array}{l}\text { Poor } \\
(\%)\end{array}$ & $\begin{array}{c}\text { Not Poor } \\
\text { (\%) }\end{array}$ & $\begin{array}{l}\text { Poor } \\
(\%)\end{array}$ \\
\hline \multirow{4}{*}{$\begin{array}{c}\text { No } \\
\text { Pandemic } \\
\text { Baseline }\end{array}$} & Not Poor & 78.5 & 4.9 & 81.5 & 1.9 \\
\hline & & {$[77.2,80.2]$} & {$[3.2,6.3]$} & {$[80.5,82.3]$} & {$[1.1,3.0]$} \\
\hline & Poor & 0.4 & 16.2 & 0.6 & 16 \\
\hline & & {$[0.1,1.1]$} & {$[15.5,16.5]$} & {$[0.2,1.2]$} & {$[15.4,16.4]$} \\
\hline
\end{tabular}

We examine the household income changes underlying these income poverty transitions in Table 3, where we tabulate the income changes faced by households moving above and below the income poverty line in Scenarios A and B. It's clear that households who fall into income poverty in Scenario A and B face very large income losses. These range from 54.5 to 77.2 per cent of household disposable income in Scenario A but decrease substantially in Scenario B to between 30.8 and 68.3 per cent of disposable household income. These substantial losses contrast 
with the more muted losses incurred by the majority of poor households - those who are poor in both the No Pandemic Baseline and the Pandemic scenarios, whether Scenario A or B. In Scenario A, these households face income losses of between 2.7 and 0.6 per cent. In Scenario B, they face income losses of at most 0.8 per cent, but can also incur income gains of as high as 0.8 per cent after accruing temporarily higher income from PUP and some smaller gains from the Fuel

Allowance extension.

\begin{tabular}{|c|c|c|c|c|c|}
\hline & & \multicolumn{2}{|c|}{ Scenario A (No Recovery) } & \multicolumn{2}{|c|}{ Scenario B (Recovery) } \\
\hline & & $\begin{array}{c}\text { Not Poor } \\
(\%)\end{array}$ & $\begin{array}{l}\text { Poor } \\
(\%)\end{array}$ & $\begin{array}{c}\text { Not Poor } \\
\text { (\%) }\end{array}$ & $\begin{array}{c}\text { Poor } \\
(\%)\end{array}$ \\
\hline \multirow{4}{*}{$\begin{array}{c}\text { No } \\
\text { Pandemic } \\
\text { Baseline }\end{array}$} & Not Poor & -8.5 & -67.6 & -4.4 & -50.3 \\
\hline & & {$[-9.7,-7.6]$} & {$[-77.2,-54.5]$} & {$[-5.6,-3.8]$} & {$[-68.3,-30.8]$} \\
\hline & Poor & 19.1 & -1.6 & 15.3 & 0.1 \\
\hline & & {$[15.3,24.8]$} & {$[-2.7,-0.6]$} & {$[11.8,20.0]$} & {$[-0.8,0.8]$} \\
\hline
\end{tabular}

Source: Authors' estimates using EUROMOD and 2017 Irish EU-SILC UDB, with incomes uprated to start of 2020 levels.

Note: The table tabulates the average income change for households in each transition cell. The average over 100 iterations of Scenarios A and B is shown. The minimum and maximum values from the 100 iterations are shown in parentheses.

\section{CONCLUSIONS}

During the 2008 Great Recession, the unemployment rate in Ireland increased to a high of 15 per cent. Paradoxically, the income poverty rate did not fluctuate much during that period. It increased from 14 per cent in 2008 to 15 per cent in 2013 at the peak of the recession. However, using a measure of income poverty anchored in 2004 showed that income poverty fell during the economic expansion but rose sharply as Ireland fell into recession. Unlike the income poverty rate, the basic deprivation rate increased dramatically over the same period, from 14 per cent to a high of 30 per cent. Moreover, even before the Great Recession, exposure to poverty varied extensively across the population, with children facing the worst outcomes compared to working-age adults and older people. While the income poverty rate for children increased from only 18 per cent in 2008 to 19 per cent in 2013 , the measure of deprivation increased dramatically for all age groups of the population but reached highest levels for children. Indeed, the material deprivation rate for children increased from 18 per cent in 2008 to 37 per cent in 2013. The corresponding figures for older people rose from 9 to 16 per cent.

The recent surge of unemployment to unprecedented levels due to the COVID-19 pandemic naturally leads to concerns about poverty levels, particularly among children as policy measures to date have not specifically targeted children. Parental 
employment and higher work intensity among potential earners safeguard children from experiencing income poverty and deprivation. This was particularly evident in the Irish experience of the Great Recession. We estimate the impact of large-scale employment losses and countervailing emergency income-support measures on income poverty rates in two scenarios. The first of these, Scenario A, allows for no economic recovery; widespread employment losses and government income-support measures, PUP and TWSS, persist for the entirety of 2020. The second scenario, Scenario B, is identical to Scenario A but assumes that between 61 and 82 per cent of displaced workers return to work by the end of September 2020. We compare income poverty changes in these two scenarios to another counterfactual, a No Pandemic Baseline scenario, where we estimate income poverty rates based on income levels at the start of 2020 and in the absence of COVID-19-related employment losses and emergency income-support measures.

We find that, in the absence of an economic recovery, child income poverty rates will increase substantially, by at least 2.9 percentage points and at most 6 percentage points relative to the No Pandemic Baseline. These represent large increases in child income poverty and result in child income poverty rates increasing by at least one-sixth and at most one-third. Once we account for a partial economic recovery, the combination of emergency income-support measures and a return to work means that child income poverty rates rise only moderately - by at least 0.2 percentage points and at most 2.4 percentage points (a maximum increase in the child income poverty rate of one-seventh).

Policymakers should bear in mind that children now falling below the income poverty line in both our analysed scenarios tend to live in households that experienced large income losses because of employment losses. Policies which increase the child-dependent components of social welfare schemes or universal increases to child benefit would help to combat these income losses. However, a changing composition of expenditure could also counteract some of these income falls. O'Donoghue et al. (2020) show that, in Ireland, childcare and work-related expenses fell significantly during the lockdown period. Our analysis does not account for the effect of expenditure changes on the incidence of poverty, but these could also play in a role in further reducing the rise in poverty associated with mass employment losses.

An important final point we wish to stress is that the experience of the 2008 Great Recession showed that non-financial measures of well-being and living standards such as the basic deprivation rate also highlight the hardship that households were facing. These measures will be available for analysis once the SILC 2020 is collected, but policymakers should also be aware that non-financial measures of well-being and living standards can further demonstrate the hardship brought about by changing economic circumstances, financial stress and a changing composition of household income. 


\section{References}

Beirne, K., Doorley, K., Regan, M., Tuda, D., and Roantree, B. (2020). The potential costs and distributional effect of COVID-19 related unemployment in Ireland, Budget Perspectives 2021, Paper 1. Dublin; Economic and Social Research Institute.

Bolger, K.E., Patterson, C.J., Thompson, W.W., and Kupersmidt, J.B. (1995). Psychosocial adjustment among children experiencing persistent and intermittent family economic hardship, Child Development 66, 1107-1129.

Bronka, P., Collado, D., and Richiardi, M. (2020). The Covid-19 Crisis Response Helps the Poor: The Distributional and Budgetary Consequences of the UK Lock-down, EUROMOD Working Paper Series: EM 11/20.

Brooks-Gunn, J. and Duncan, G. J. (1997). The effects of poverty on children. Future of Children, 7, 55-71.

Caputo, R.K. (1991). Durations of work and poverty among working poor household heads: comparison of blacks and whites by selected characteristics, Association Paper: American Sociological Association (ASA).

Central Bank of Ireland (2020). Quarterly Bulletin QB2- April 2020.

Central Statistics Office (2020a). Business Impact of COVID-19 Survey. Available online at: www.cso.ie/en/releasesandpublications/er/bic19/businessimpactofcovid19survey20aprilto3may2020.

Central Statistics Office (2020b). Persons aged 15 years and over in Employment (ILO) (Thousand) by NACE.

Department for Work and Pensions (2007). Opportunity for All. London: DWP.

Department of Employment Affairs and Social Protection (2020). Update on Payments Awarded for Covid-19 Pandemic Unemployment Payment And Enhanced Illness Benefit Statistics. Available online at: www.gov.ie/pdf/?file=https://assets.gov.ie/73358/8364841f510447269ea2c8d92 d4f6730.pdf\#page $=1$.

Department of Finance (2020). Draft Stability Programme Update 2020.

Doorley, K., Bercholz, M., Keane, C., Callan, T., and Walsh, J.R. (2018). The gender impact of Irish budgetary policy. Dublin: Economic and Social Research Institute and Parliamentary Budget Office.

Duncan, G.J., Magnuson, K., Kalil, A. and Ziol-Guest, K. (2012). The importance of early childhood poverty, Social Indicators Research 108, 87-98.

European Commission (2016). Employment and Social Developments in Europe 2015, Brussels: European Commission.

European Commission (2010). The European Platform against Poverty and Social Exclusion: A European framework for social and territorial cohesion, Brussels: European Commission. 
Grotti, R., Maître, B., Watson, D., Whelan, C. T. (2018). Poverty Transitions in Ireland: An Analysis of the Longitudinal Central Statistics Office (CSO) Survey on Income and Living Conditions (SILC), 2004 - 2015, Social Inclusion Technical Paper No. 8, Dublin: The Department of Social Protection and the ESRI.

International Labour Organisation (2005). Decent Work and Poverty Reduction Strategies: A Reference Manual for ILO Staff and Constituents. Geneva: ILO (International Labour Office).

Maître, B., Nolan, B. and Whelan, C.T. (2006). Reconfiguring the Measurement of Deprivation and Consistent Poverty in Ireland, Policy Research Series Number 58, Dublin: Economic and Social Research Institute.

McGuiness, S., McGinnity, F. and O'Connell, P. (2009). Changing Returns to Education during a Boom? The Case of Ireland. Labour: Review of Labour Economics and Industrial Relations, 23(s1) 197-221.

McQuinn, K., O'Toole, C., Allen-Coghlan, M. and Coffey, C. (2020). Quarterly Economic Commentary, Summer 2020, Economic and Social Research Institute.

O'Donoghue, C., Sologan, D.M., Kyzyma, I. and McHale, J. (2020). Modelling the Distributional Impact of the Covid-19 Crisis. Fiscal Studies.

Organisation for Economic Co-operation and Development (1998). Patterns of employment and joblessness: a household perspective, Chapter 1C, Employment Outlook. Paris: OECD (Organisation for Economic Co-operation and Development).

Organisation for Economic Co-operation and Development (2004). Jobless Households, OECD Observer no. 245, Paris: OECD (Organisation for Economic Co-operation and Development).

Redmond, P. (2020). Minimum Wage Policy in Ireland, Budget Perspectives 2021, Paper 2. Dublin: Economic and Social Research Institute.

Regan, M., Keane, C., and Walsh, J.R. (2018). Budget Perspectives 2019, Paper 1. LoneParent Incomes and Work Incentives. July 2018.

Revenue Commissioners (2020a). COVID-19 Temporary Wage Subsidy Scheme. Available online at:

www.revenue.ie/en/corporate/documents/statistics/registrations/wage-subsidyscheme-statistics-23-april-20.pdf.

Revenue Commissioners (2020b). COVID-19 Temporary Wage Subsidy Scheme. Available online at:

www.revenue.ie/en/corporate/documents/statistics/registrations/wage-subsidyscheme-statistics-18-june-2020. pdf.

Savage, M., Callan, T., Keane, C., Kelly, E. and Walsh, J.R. (2014). Welfare targeting and work incentives, Budget Perspectives 2015, Paper 3. Dublin; Economic and Social Research Institute.

Watson, D., Whelan, C.T., Maître, B. and Williams, J. (2017). Non-Monetary Indicators and Multiple Dimensions: The ESRI Approach to Poverty Measurement, The Economic and Social Review, Economic and Social Studies, 48(4), 369-392. 
Watson, D., Whelan, C.T., Maître, B. and Williams, J. (2016). Socio-Economic Variation in the Impact of the Irish Recession on the Experience of Economic Stress among Families, The Economic and Social Review, 47(4): 477-498.

Watson, D., Maître, B. and Whelan, C.T. (2012). Work and Poverty in Ireland: An Analysis of the CSO Survey on Income and Living Conditions 2004-2010. Dublin: ESRI and Social Inclusion Division of Department of Social Protection.

Watson, D. and Maître, B. (2013). Social Transfers and Poverty Alleviation in Ireland: An Analysis of the Survey on Income and Living Conditions 2004 - 2011. Dublin: ESRI and Social Inclusion Division of Department of Social Protection. 


\begin{tabular}{|c|c|c|c|c|c|c|}
\hline & \multicolumn{2}{|c|}{ At work } & \multicolumn{2}{|c|}{ Unemployed } & \multicolumn{2}{|c|}{ Inactive } \\
\hline & $\begin{array}{l}\text { AROP } \\
(\%)\end{array}$ & $\begin{array}{c}\text { Deprivation } \\
(\%)\end{array}$ & $\begin{array}{l}\text { AROP } \\
(\%)\end{array}$ & $\begin{array}{l}\text { Deprivation } \\
(\%)\end{array}$ & $\begin{array}{l}\text { AROP } \\
(\%)\end{array}$ & $\begin{array}{c}\text { Deprivation } \\
\text { (\%) }\end{array}$ \\
\hline & \multicolumn{6}{|c|}{$2007 \& 2008$} \\
\hline 1 adult with children & 19.9 & 27.5 & $* *$ & $* *$ & 71.7 & 54.9 \\
\hline 2 adults with 1-3 children & 8.4 & 8.3 & 37.1 & 40.7 & 26.6 & 24.9 \\
\hline \multirow[t]{2}{*}{$\begin{array}{l}\text { Other households with } \\
\text { children }\end{array}$} & 14.3 & 8.9 & 41.3 & 44.9 & 28.3 & 31.1 \\
\hline & \multicolumn{6}{|c|}{$2013 \& 2014$} \\
\hline 1 adult with children & 15.1 & 52.1 & 51.7 & 72.2 & 58.1 & 70.5 \\
\hline 2 adults with $1-3$ children & 5.8 & 20.6 & 37.4 & 62.8 & 26.9 & 55.5 \\
\hline \multirow[t]{2}{*}{$\begin{array}{l}\text { Other households with } \\
\text { children }\end{array}$} & 15.5 & 27.6 & 60.1 & 67.1 & 38.4 & 48.0 \\
\hline & \multicolumn{6}{|c|}{$2017 \& 2018$} \\
\hline 1 adult with children & 18.6 & 29.5 & 56.1 & 45.2 & 63.3 & 66.8 \\
\hline 2 adults with $1-3$ children & 4.9 & 9.6 & 44.7 & 49.0 & 32.1 & 40.1 \\
\hline $\begin{array}{l}\text { Other households with } \\
\text { children }\end{array}$ & 14.1 & 16.5 & 62.4 & 60.0 & 37.3 & 37.3 \\
\hline
\end{tabular}

Source: $\quad$ Authors' calculations using SILC RMF for 2007, 2008, 2013, 2014, 2017 and 2018.

Note: 'AROP' is the 'at risk of poverty' measure. 'Deprivation' is the rate of basic deprivation. A child is defined as an individual less than 18 years of age. The double asterisk $\left(*^{*}\right)$ indicates a blank cell due to insufficient sample cases as per the CSO statistical disclosure guidelines. 


\section{APPENDIX 2: SIMULATION METHODOLOGY}

We estimate how household incomes and subsequent poverty rates evolve through 2020 using a Monte Carlo approach which allows the size of the economic downturn, rate of economic recovery and degree of wage reductions to vary. More details on the two scenarios analysed in the text are given below. We explain Scenarios $A$ and $B$ in four phases, each of which represents different time periods through 2020.

\section{Scenario A: No Recovery}

1. In Phase 1, normal economic circumstances prevail. We use EUROMOD to simulate household incomes under the tax-benefit rules in place at 1 January 2020. This lasts for the first 11 weeks of the year.

2. In Phase 2, there are large COVID-19-related employment losses which vary by industry. The portion of workers displaced randomly varies between a minimum and a maximum threshold per industry, as outlined in Table A2. The probability density function between these minimum and maximum values is a uniform distribution, meaning that all values in the interval are equally as likely to be drawn.

a. A proportion of shocked workers in each industry are displaced. The minimum and maximum bounds of the shock are shown in Table A2. A set portion of displaced workers in each industry become eligible for TWSS and PUP, as per Table A3. A total of 84 per cent of those who become eligible for TWSS receive a top-up payment from their employer. Workers who receive PUP work 0 hours per week. Workers who receive TWSS are randomly assigned a number of hours worked between 0 and their last reported weekly hours worked in Phase 1. This determines the level of top-up an employee receives from their employer. Employees receive a top-up proportional to their new hours of work. Those who work the same number of hours as before receive their full weekly net wage, whereas those who work half their normal hours will be topped up by half the difference between their usual weekly net wage and the government minimum subsidy level. Intuitively, employers give larger top-ups to employees who remain in work.

b. We model the latest version of PUP and model the TWSS as at 4 May. We do not deduct tax from PUP as it is not deducted at source and we assume this tax is a 2021 liability. We model TWSS as described in Section 5 of this paper. We assume that employers top up their employees earning more than $€ 586$ per week to a maximum of 60 per cent of the previous net wage as this maximises the contribution from the State. Employees earning less than $€ 586$ can receive the remainder of their net weekly wage if they receive a top-up payment. We assume that 84 per cent of employees receive a top-up payment. We then 
calculate household incomes using these modified tax-benefit rules.

c. Phase 2 lasts for the remainder of the year. PUP is paid at $€ 350$ per week for 12 weeks and for the remainder of the year at $€ 350$ for those whose prior earnings were $>=€ 200$ per week and at a rate of $€ 203$ per week for workers earning less than €200 per week.

We repeat this process 100 times with different random samples of workers losing employment in Phase 2.

\section{Scenario B: Recovery}

1. Phase 1 is identical to that described in Scenario $A$.

2. Phase 2 is identical to that described in Scenario A except this phase now lasts 12 weeks as opposed to the remainder of the year. The PUP rate is a flat fee of $€ 350$ per week.

3. In Phase 3, a random portion of workers who lost employment in Phase 2 return to work. This phase lasts for 14.5 weeks. The portion who return to work varies between 44 and 64 per cent. This job-finding rate does not vary by industry and is calculated over all displaced workers. Workers who return to work receive a lower hourly wage than they earned in Phase 1 . The loss varies between 10 and 15 per cent to account for wage-scarring. They return to work at their usual hours of work. These recovery parameters are shown in Table A4. The probability density function is uniform between the minimum and maximum values. We simulate a tapered version of emergency policy benefits in this period. The tapered measures are:

a. The PUP rate is $€ 203$ for those earning less than $€ 200$ per week and $€ 350$ for all other workers.

b. The TWSS is unchanged.

4. In Phase 4, a further portion of workers who lost employment in Phase 2 but did not find employment in Phase 3 return to work. The portion of displaced workers who return to work in Phase 4 varies between 31 and 51 per cent. As in Phase 3 , they suffer wage losses between 10 and 15 per cent, to account for scarring. PUP and TWSS are the same as in Phase 3. This phase lasts the remaining 14.5 weeks of the year.

We repeat this process 100 times with different random samples of workers losing employment and further random sub-samples returning to work in each simulation. 


\begin{tabular}{|l|c|c|}
\hline Industry & Min. Loss of Employment (\%) & Max. Loss of Employment (\%) \\
\hline Agriculture and Fishing & 9 & 11 \\
\hline Mining, Manufacturing and Utilities & 23 & 28 \\
\hline Construction & 65 & 79 \\
\hline Wholesale and Retail Trade & 43 & 53 \\
\hline Hotels and Restaurants & 79 & 95 \\
\hline Transport and Communication & 13 & 16 \\
\hline Financial Intermediation & 12 & 15 \\
\hline Real Estate and Business Activities & 32 & 39 \\
\hline Public Administration and Defence & 11 & 14 \\
\hline Education & 13 & 15 \\
\hline Health and Social work & 8 & 10 \\
\hline Other & 46 & 55
\end{tabular}

Source: Author's analysis using data from CSO, Revenue Commissioners and DEASP. We allow a ten percent spread either side of baseline employment losses in each industry.

TABLE A3 PORTION OF DISPLACED WORKERS WHO RECEIVE PUP AND TWSS

\begin{tabular}{l|c|c|}
\hline Industry & TWSS (\%) & PUP (\%) \\
\hline Agriculture and Fishing & 24 & 76 \\
\hline Mining, Manufacturing and Utilities & 52 & 48 \\
\hline Construction & 28 & 72 \\
\hline Wholesale and Retail trade & 41 & 59 \\
\hline Hotels and Restaurants & 19 & 81 \\
\hline Transport and Communication & 81 & 19 \\
\hline Financial Intermediation & 16 & 84 \\
\hline Real Estate and Business Activities & 18 & 82 \\
\hline Public Administration and Defence & 5 & 95 \\
\hline Education & 19 & 81 \\
\hline Health and Social work & 10 & 90 \\
\hline Other & 11 & 89 \\
\hline
\end{tabular}

Source: $\quad$ Authors' analysis using data from Revenue Commissioners and DEASP.

\begin{tabular}{l|c|c|}
\hline Industry & Min. Value (\%) & Max. Value (\%) \\
\hline Job-Finding Rate in Phase 3 & 44 & 64 \\
\hline Job-Finding Rate in Phase 4 & 31 & 51 \\
\hline Wage Losses in Phase 3 & 10 & 15 \\
\hline Wage Losses in Phase 4 & 10 & 15
\end{tabular}

Source: Job-finding rates are derived from projections of the number of unemployed individuals in Q1-Q4 2020 in the Central Bank Quarterly Bulletin for Q2 2020. We allow a ten-percentage point spread from baseline job-find rates derived from these quarterly estimates. Wage losses are according to authors' own judgement. 
Whitaker Square,

Sir John Rogerson's Quay,

Dublin 2

Telephone +35318632000

Email admin@esri.ie

Web www.esri.ie

Twitter @ESRIDublin 